\title{
Albania: education, employment and social policies - lost in translation
}

\begin{abstract}
Employment constitutes one of the most crucial economic and social issues in Albanian society. In the last decade, Albania has made progress in its social, economic and political development, but it still remains among the poorest countries in Europe and faces a number of challenges. Increasing employment should become a priority for the country's socio-economic policies; this would have a direct effect on poverty reduction as well as on the inclusion of all citizens in social, economic and political life. The present situation is also significant if linked to the low level of education in the country. In fact, the present education system is failing to produce a critical mass of human capital that generates external positive factors for the labour market. Consequently, the poor quality of education has a direct negative impact on economic growth in Albania. It is disturbing that, even in the presence of these disadvantages in the skills of the labour force, Albania is yet to invest sufficiently in education. Indeed, it spends significantly less on education than other countries in the region. Policies for employment should be accompanied by investment in the skills and human capital necessary to have a positive impact on the labour market.
\end{abstract}

Keywords: transition, reform, employment, participation rates, informal economy, social policy, poverty, decentralisation, tax transparency, infrastructure quality, education system, economic growth, inequalities, labour migration

\section{Introduction}

The Republic of Albania is situated in the region of south-east Europe, south-west of the Balkan Peninsula and along the Adriatic and Ionian seas. The territory of Albania is $28748 \mathrm{~km}^{2}$ and its population is $3170048 .{ }^{1}$ The population is growing at a low rate, with the main factors being migration, which is relatively high, and the continuous decrease in the number of births.

The communist regime collapsed in 1990 and the Republic of Albania was founded in 1991 as a parliamentary democracy established under a constitution renewed in 1998. The administrative division of the country consists of 12 prefectures, 36 districts and 374 communes/municipalities.

1 INSTAT - Albanian National Institute of Statistics [last accessed 20 January 2011]. Statistics for 2001 are taken from the results of the Population and Household Census, accomplished in April 2001. 
Albania is largely an ethnically homogeneous country, with only small minorities. The large majority of the population is ethnically Albanian. The exact size of minority ethnic groups is not known, as the last census that contained ethnographic data was held in 1989. The next census containing ethnographic data began in April 2011, with EU advisers assisting in certain fields. ${ }^{2}$ Minorities include Greeks, Vlachs, Macedonians, Serbs, Bulgarians, Balkan Egyptians and Roma.

The transition from a planned to a free-market economy has proven challenging as successive governments have tried to deal with high unemployment, widespread corruption, a decaying physical infrastructure and widespread social problems, especially in rural areas. Albania's economy continues to grow, but the country is still one of the poorest in Europe, hampered by a large informal economy and an inadequate energy and transportation infrastructure.

The Albanian economy recorded growth of $6 \%$ in the first quarter of 2009 , mainly driven by large public investment in the road network. So far, the international financial and economic crisis has resulted in lower demand for Albanian exports, a fall in the net inflows of monetary transfers in the form of remittances and a marked slowdown in the growth of credit. There have been some improvements in labour market outcomes. However, unemployment remains high and the labour market data continue to be poor. ${ }^{3}$ The most recent EU progress report on Albania indicates that there has been little progress in the field of social policies. ${ }^{4}$

Regional disparities are present in an extreme form in Albania: poverty is $66 \%$ higher in rural areas than in Tiranë and $50 \%$ higher in rural areas than in other major urban centres. Internal migration is the result of such massive internal disparities: between 2005 and 2006 alone the population of Tiranë increased by 137000 . The measurement of disadvantage at district level indicates that wealth is unequally distributed among the regions. The same pattern of unequal distribution is shown at commune level -i.e. within the district - demonstrating that disadvantaged communes exist even within less disadvantaged counties. ${ }^{5}$

Albania is now a member of the United Nations, NATO, the Organization for Security and Co-operation in Europe, the Council of Europe, the World Trade Organization and the Organisation of the Islamic Conference, and is one of the founding members of the Union for the Mediterranean. Albania has been a potential candidate for accession to the European Union since January 2003, and it formally applied for EU membership on 28 April 2009.

\section{The case for a trade-off in employment policy}

Employment constitutes one of the most crucial economic and social issues in Albanian society. It is a multi-sectoral phenomenon which should encompass macro-

2 Albania to hold census in 2011 [last accessed 20 January 2011].

3 Commission of the European Communities (2010) 'Albania 2009 Progress Report' Enlargement Strategy and Main Challenges 2009-2010.

4 ibid.

5 Ministry of Economy, Trade And Energy (2007) Regional development Cross-Cutting Strategy October. 
economic policies; business-friendly policies; education policies; and social policies. In the last decade, Albania has made progress in its social, economic and political development, but it still remains among the poorest countries in Europe and faces a number of challenges. Albania has an annual per capita national income of just $\$ 2960$ and is classified as a below middle-income country. ${ }^{6}$

After the deep recession of 1997-1998, Albania achieved macroeconomic stability in the early $2000 \mathrm{~s}$, together with economic growth proceeding on average at a rate of $5 \%$ yearly. Poverty dropped from $25.4 \%$ in 2002 to $18.5 \%$ in 2005 . This can be marked as progress towards achieving Millennium Development Goal No. 1 which, in Albania, aims to cut the poverty rate to $13 \%$ by $2015 .{ }^{7}$ Nevertheless, these figures of progress do not necessarily translate into the opening of new job opportunities. In fact, much of the present level of consumption is mainly sustained by emigrant remittances, as well as by increased access to loans from second-level banks. ${ }^{8}$

According to the Labour Force Survey $2009,{ }^{9}$ the working age population in Albania comprises $87.9 \%$ of the total population aged 15 years and over. The country's working-age population is that which is actively engaged in the labour market, either by working or by looking for a job. This being explained, the labour force participation rate in Albania in 2009 is $61.9 \%$, with the female worker participation rate showing a decreasing trend between 2007 and 2009 while the male employment rate increased compared to $2008 .^{10}$

If we examine these data further, it will be noticed that the employment rate is higher among those belonging to the 35-54 age group, while the trend is comparatively similar. According to the same survey, the employment structure by sector reveals that there is a declining trend in employment in the agricultural private sector while employment in the non-agricultural private sector is showing an increase.

As for the unemployment rate, the Labour Force Survey in 2009 shows it to be $13.8 \%$. The youth unemployment rate (among 15-24 year-olds) was $27.2 \%$ in 2009 , while the adult unemployment rate (aged 25-64) is $11.3 \%$. The ratio between the youth unemployment rate and the adult unemployment rate for 2009 is 2.4 , which means that young people are 2.4 times less likely than adults to find a job in the labour market.

In contrast, the non-economically active population, i.e. people away from the labour force, consists of $38.1 \%$ of the working age population. This contingent is made up of people who are classified neither as employed nor as unemployed. The Labour Force Survey for 2009 discloses that, among the non-economically active population:

- 36.1 per cent are pupils and students

- 19.8 per cent are in retirement

6 International Labour Organization ILO (2010) Analysis of the youth labour market in Albania.

7 World Bank (2007) Albania Country Brief.

8 Agenda Institute (2008) Challenges facing Albanian youth on the road towards employment Tiranë.

9 Albanian Institute of Statistics (2009) Labour Force Survey 2009 [last accessed 23 January 2011].

10 ibid. 
- 16 per cent are discouraged unemployed

- 14.5 per cent are fulfilling domestic tasks. ${ }^{11}$

Pensions have significantly lost their real value due to the rapid inflation in the past. The low level of pensions has increased old-age poverty and, consequently, the numbers of recipients of social assistance. Meanwhile, the financing of the pension scheme presents problems. Currently, due to the insufficient level of contribution income, about $25 \%$ of urban pensions and $70 \%{ }^{12}$ of rural ones are subsidised by the Albanian government. It is thus essential that pension reforms are started in order to provide benefits for this vulnerable category of the population and also finally to establish sustainable schemes for the future.

When elaborating the key employment issues in Albania, we cannot avoid mentioning the issue of child labour. According to the Albanian Institute of Statistics, $32 \%$ of children between 6 and 17 years old in the country are working. The worst forms of child labour are among street children; the trafficking of children; children being involved in illicit activities; children working in the formal sector; and children working in the agriculture sector. The main reasons for child labour are poverty; their parents' unemployment or migration; and a disrupted family environment; as well as education-related reasons such as poor school attendance; a lack of schools near a residential area; expulsion from school; poor performance at school; and a dislike of school. ${ }^{13}$ This automatically leads to a lack of education, or the ill-education, of this contingent which, in the near future, will have dramatic consequences for them as individuals where they have no skills with which to compete in the labour market. If continued, this phenomenon will have an important impact on the perpetuation of the cycle of poverty over the generations in Albania.

Generally, the youth unemployment rate has been consistently higher than that of adults throughout the entire past decade. Employment prospects for young people are rather lacking. ${ }^{14}$ The trends show that the employment rate of young women is $5 \%$ lower than that of young men. In addition, employment figures show that most young people living in rural areas are engaged in farming, either as self-employed or as contributing family members.

One of the major issues that is negatively influencing the Albanian economy is the widespread phenomenon of the informal economy. This causes losses in revenues from tax evasion, distorts the labour market, hides the true unemployment figures and encourages unfair competition. Common features of work in the informal economy are represented by the lack of an employment contract, as well as of paid annual and sick leave and other social security benefits. The informal economy at large, and in Albania in particular, entails serious costs for individuals, enterprises and society as a whole. The informal economy is estimated to contribute about one-third of total gross domestic

11 ibid.

12 Albanian Institute of Statistics [last accessed 23 January 2011].

13 International Labour Organization Decent Work Country Program 2008-2010.

14 Albanian Institute of Statistics Living Standard Measurement Survey 2005 [last accessed 23 January 2011]. 
product (GDP) in Albania. Some $55 \%$ of workers in the non-agricultural sector are engaged in low-productivity jobs in the informal economy. ${ }^{15}$

The informal sector in Albania is bigger in urban areas $(24 \%)$ than in rural ones ( $5 \%$ ). Around $15 \%$ of employees in Tiranë, the capital, work on their own or in nonfarming family enterprises. ${ }^{16}$ Young workers take a large stake in the informal economy; and the likelihood of being an informal worker is significantly correlated with being young, male and having a low educational attainment. ${ }^{17}$

Any exploration of the employment landscape in Albania would not be complete without information and data on self-employment which, as a concept, was introduced for the first time in Albania after the closure of public industrial enterprises and the reconstruction of the country's economy. Self-employment in Albania has a family business character, mainly in trade and family-inherited crafts roles. Sixty two per cent of employees work full-time and 39\% part time, while more full-time employees are men $(70 \%)$ than women $(51 \%)$. Estimates run much higher for workers in agriculture, where most are self-employed or own-account workers, and one-half are poor. ${ }^{18}$

Over the past two decades, Albania has experienced high rates of migration and emigration. It is estimated that about $40 \%$ of the working-age population works abroad. ${ }^{19}$ Migration has for years been a way of countering low-paid jobs, unemployment and poverty. The data on poverty indicate that the categories of the population facing a higher risk of poverty are the unemployed, the less educated and people living in rural areas with fewer public services.

\section{Related legal and institutional infrastructure}

The priorities of the Ministry of Labour, Social Affairs and Equal Opportunities for the period 2007-2013 are set out in the strategies on Employment and Vocational Training, Social Inclusion and Gender Equality and Domestic Violence, all approved in 2007, as well as in the National Strategy on Migration that was approved in 2004. The objectives of the Employment and Vocational Training Strategy are centred on the promotion of an active employment policy through the establishment of a modern system of employment services; the development of proactive policies on employment; the strengthening of the vocational education and training system; the reduction of informal employment; the improvement of conditions of work; and the promotion of social dialogue. ${ }^{20}$ This policy of employment is also backed by the Strategy on Gender Equality and Domestic Violence, while the Social Inclusion Strategy pays special attention to measures for reducing the vulnerability of informal workers.

15 Ministry of Labour, Social Affairs and Equal Opportunities Strategy for Social Inclusion 2007-2013.

16 ibid.

17 Elaboration is based on this survey. Albanian Institute of Statistics Living Standard Measurement Survey 2005 op. cit.

18 Ministry of Labour, Social Affairs and Equal Opportunities, op. cit.

19 International Labour Organization Decent Work Country Program 2008-2010.

20 Ministry of Labour, Social Affairs and Equal Opportunities Sectoral Strategy on Employment and Vocational Training (2007-2013). 
The fundamental law in the field of employment is Law No. 7995, dated 30 September 1995, On the encouragement of employment. This law supports both the implementation of programmes for the development of employment and the establishment of the National Employment Service and the National Employment Fund. The Law has also created the first basis of a package of programmes, such as:

a) intermediation for jobs and professions

b) job and professional counselling

c) vocational training

d) employment encouragement programmes, etc.

The last changes to the law, approved in July 2006, have improved some issues related to:

a) the upgrading of its definitions and the inclusion of new ones related to different programmes and categories of people benefiting from this law

b) the introduction of the concept of counselling and professional orientation as part of employment services

c) the creation of new programmes, such as that on professional practice for young people

d) a change in the management procedures for the vocational training funds. This is a consequence of the entry into force of Law No. 8872, dated 19 March 2002, On Vocational Education and Training in the Republic of Albania and the approval of a statute setting out a template for public vocational training centres.

The public employment service is implemented in the context of the labour market by the National Employment Service. This is an autonomous public service with the status of a central state administration, reporting to the Minister of Labour, Social Affairs and Equal Opportunities. The highest decision-making authority of the National Employment Service is its Trilateral Administrative Council, which operates with the participation of three employer representatives, three employee representatives and seven representatives of the state. The services offered by the NES include activities such as:

a) registration of jobseekers

b) job intermediation (job supply and demand matching)

c) jobseekers' orientation and counselling

d) preparation of documentation for unemployment benefits

e) orientation towards, and appointments to, vocational training courses

f) collection of information on the labour market

g) implementation of employment encouragement programmes.

Despite shifting from passive policies to active ones, it is evident that the state employment services should be oriented toward the ownership and improvement of the labour market situation. Currently, about $47 \%$ of the total number of staff in Employment Offices work and provide services to 149000 unemployed jobseekers registered with the Offices while, in EU countries, this percentage is $62-65 \% .^{21}$

In October 2007, the government of Albania launched the National Strategy for Development and Integration (NSDI) for the period 2007-2013. The Strategy in itself

\section{1 ibid.}


aims to achieve rapid, balanced and sustainable economic, social and human development. Among others, the strategy assigns high priority to policies giving a stronger role to young people in the economy.

The National Labour Council (NLC) was established in 1996 with the aim of serving as a forum for tripartite consultations between government and the social partners. At present, the Council meets to discuss substantive issues, such as employment strategies, social security measures and equal opportunities and non-discrimination in the labour market, although it does not do so particularly regularly. Seven government ministers participate in its sessions, including the Minister of Labour, Social Affairs and Equal Opportunities; the Minister of Finance; the Minister of Health; the Minister of Education and Sciences; the Minister of Justice; the Minister of Economy, Trade and Energy; and the Minister of Public Works, Transportation and Telecommunications.

\section{The case for a trade-off in social policy}

Equitable and inclusive growth is very important in promoting economic and social development. It is important that development processes do not exclude anyone. There are groups in Albanian society who are at risk of deprivation, or for whom barriers exist that do not allow them to be fully included in society, and, for this reason, if policies are to be effective, they must be targeted to meeting the needs of these groups. The poverty rate in Albania is among the highest in Europe. Data analysis shows that poverty reduction could have been faster had inequality not increased and had all of the poor benefited equally from economic growth. ${ }^{22}$

Social protection programmes have a significant impact on poverty in Albania. The social protection system includes:

a) contributions-based social security scheme

b) labour market programmes funded from incomes

c) social assistance in the form of state budget transfers.

The total value of public transfers focused on social protection constitutes $28 \%$ of the consumption of the poorest $20 \%$ of rural families; and $38 \%$ of the consumption of the poorest $20 \%$ of families from urban areas. In the absence of social protection programmes, the poverty rate would have been $11 \%$ higher for the population and $20 \%$ higher for the beneficiaries. ${ }^{23}$

In the field of social assistance, the state offers a number of programmes.

Firstly, Economic Assistance helps approximately 120000 households with a monthly cash payment, 69000 of whom are from rural areas and 51000 from urban ones (2005). Economic Assistance is provided at a lower, or secondary, level for $57 \%$ of households (mainly in rural areas); and at a higher level for $43 \%$ of households (mainly in the city). The coverage of the poor has increased, but there are problems with the amount of economic aid which partially covers the needs of poor families ( $67 \%$ of them are not covered). The real value of payments has decreased in $27 \%$ of 
urban areas and $17 \%$ of rural areas and, on average, represents $15 \%$ of the poverty line. ${ }^{24}$

Secondly, Payment for Disability, a programme targeted at people with disabilities, is the largest programme of social assistance and has experienced a rapid expansion in the number of beneficiaries in recent years.

Recently, the Law for Assistance and Social Services (2005) has been under implementation. This law expands the limits for payments to all vulnerable groups, creates the space needed for decentralisation and expands the competences of local governance and civil society structures to participate in the provision of social care services. However, the infrastructure for the delivery of public services, including social care services, health and education services, remains very poor, while the destruction of infrastructure in the nineties and the migration of professionals have both exacerbated the situation.

Traditionally, Albania has not used the institutionalisation of social care as a way of providing services to the elderly, orphans or people with disabilities. Throughout the country, there are 26 such institutions (23 of which are residential ones). Being located in the largest urban centres, the needs for services in remote areas are only partially covered. These services are currently offered by the central government and are in the process of being decentralised to local government. Existing community services are provided by international and local NGOs. However, even these services are concentrated mainly in Tiranë and in other cities that have a better infrastructure, or in areas in which NGOs are more active and have the capacities to absorb funds. Meanwhile there is a lack of a regulatory framework for the services provided by NGOs.

The Strategy of Social Services (2005-2010) and the Law on Assistance and Social Services (2005) opens the way to de-institutionalisation and to the decentralisation of social care institutions to local governance, where services will be closer to family and community. This reform will encourage civil society in ensuring and developing new social care services in partnership with local government. The Strategy of Social Inclusion is one of the components of the National Strategy for Development and Integration. It focuses on poverty and social exclusion, as well as on the risks remaining even after economic growth. Being a cross-cutting strategy, it stems from the strategies on social protection, employment, education, health, transport, water supply, urban planning and justice which have been approved or which are in the drafting process. We should view this strategy in relation to the cross-cutting strategies of urban development, countering organised crime, terrorism and trafficking, information and communications technology, and decentralisation. The Strategy itself aims to help vulnerable groups, families and groups in the community so that they can act independently, provide income and have the same rights as other members of society.

Key issues to be addressed

Increase in employment

This should become a priority task for socio-economic policies in the country. This would directly have an effect on poverty reduction, as well as on the inclusion of all 
citizens in the social, economic and political life of the country. Policies facilitating participation in employment of specific groups, the growth of the labour market and lifelong learning and vocational training should be taking on a greater importance and focus.

Increase women's participation in the labour market

The labour force in Albania is decreasing. Data show that women are not sufficiently encouraged to enter the market and, as a consequence, are less active in searching for work. The Labour Code of $1995^{25}$ and the Law on Gender Equality of $2004^{26}$ legitimate the equal treatment of men and women, but women's incomes are, on average, lower than those of men, as is their level of participation in the labour market. ${ }^{27}$ Specific policies included in the Employment Sector Strategy do, in fact, reflect the commitment to equity and non-discrimination in favour of groups in need (women included); however, they need to be enforced efficiently and accompanied by an allocated specific budget such as, for instance, specific assistance for the training and employment of particular groups in need and the reduction of taxation for particular groups that have been excluded from the labour market. In the case of Albania, groups to be taken into consideration are: young people; victims of trafficking; former prisoners; Roma; and Egyptian women. ${ }^{28}$

\section{Transparency and enforcement of tax law}

As far as this area is concerned, there are many drawbacks and many unreported cases from employers arising from personal income tax problems and the dodging of social security contributions. Generally, those who work in the informal sector originate from poor families with limited education; they work extended hours with low salaries and social security contributions are not paid on their behalf. Consequently, they have no right to complain based on the Labour Code. Meanwhile, companies that operate in the informal market do not invest in the skills of their employees.

Improved co-operation between the National Employment Service, the State Labour Inspectorate and the Tax and Customs Office would bring about better control of the market. The Strategy for the Finance Sector $2007-2013^{29}$ predicts an equal distribution of taxes arising from the formulation of a specific policy and a set of administrative measures that would reduce the lack of motivation for informal employment by reaching a higher level of adoption. Greater emphasis should also be placed on the reduction of labour taxes, mainly through the reduction of social security contributions which have been among the highest in the region. 2011].

27 Albanian Institute of Statistics, .

28 Ministry of Labour, Social Affairs and Equal Opportunities System of tariffs for professional Education within the Strategy for Social Inclusion 2007-2013 [last accessed 24 January 2011]. 
Financing of secondary education

This has been insufficient and, as a result, has hampered the development of education in general and vocational training in particular. Such a situation implies classes with too many pupils and schools operating in shifts. ${ }^{30}$ There is a need for policies in this sector that encourage equity and inclusion such as: free academic books and tools for specific groups in need that attend elementary and secondary education; transport for children who live far from the school location (very often in poor rural areas); and special incentives for teaching posts in these remote and difficult areas. In order to break the inheritance of poverty through the generations, policies should dedicate specific attention to the occupational skilling of children from poor families. In accordance also with economic trends on the regional labour market, priority should be given to vocational qualifications in the sphere of pre-university education. A series of occupational schools should be built and opened in rural areas, with the aim of attracting $40 \%$ of pupils that conclude their basic education.

\section{Infrastructure for the delivery of public services}

The infrastructure for the delivery of public services, including social care services, health and education services, is very poor in rural areas and, especially, in urban and semi-urban areas in which there are large informal settlements caused by internal migration. A policy of the decentralisation of services in these sectors is currently being implemented. ${ }^{31}$ However, the traditional formulas used for allocating investment and current spending by central government to local government do not necessarily articulate the needs of the poor.

\section{The case for a trade-off in education policy}

A core condition for Albania becoming an EU member is, among others, having a market economy that is competitive within the EU. Education and research contribute to economic growth and competitiveness by providing highly-skilled graduates prepared to play their role in an open economy and democratic society, as well as by the creation, transfer and adaptation of knowledge. Albania has a factor-driven economy and, to facilitate growth, the country has to shift resources toward investment-driven, and ultimately toward innovation-driven, growth. Both these, but especially innovation-driven growth, require a better performance from the education system. This needs to produce an increased number of high school and university graduates equipped with the skills and knowledge necessary to respond to the demands of the market. To create a competitive economy, one that is growing and generating future-oriented jobs, requires the taking of policy measures across many sectors, including education and, above all, higher education. Research carried out by the World Bank since the early 1990s shows that the development of higher education in a country is correlated with its economic development. ${ }^{32}$

31 Ministry of Interior National Strategy on Decentralisation and Local Governance [last accessed 24 January 2011]. 
In Albania, the Ministry of Education and Science (MOES) is the central institution dealing with the drafting of state policy for pre-university education. In order to ensure the proper processing of educational policy, MOES has created a consultation entity made up of personalities in various fields, as well as leaders of education and recognised teachers. By means of specific acts, it defines curricula and teaching plans which are accomplished at the various levels of pre-university education. MOES and its subordinate institutions approve the fundamental documents, including plans, programmes and teaching texts; conduct inspections; and are entitled to experiment regarding the improvement of quality in education in compliance with international standards.

Pre-university education is undergoing continuing reformation and is also engaged in a process of decentralisation as a means of seeking an increase to the quality of this service, since it is highly important to the country's cultural development and economic growth. The service is currently a shared function between local and central government. As such, it has to cope with problems related to the sharing of functions and responsibilities between regional education departments and office and local government units.

Albania has been embarked on a path of decentralisation-based reform since 2000 and has set the competencies of local government units in the area of education to the operation and maintenance of pre-university education buildings, the payment of teachers' salaries and the making of capital investment in school buildings and related infrastructure. According to the European Charter of Local Government, ${ }^{33}$ the Constitution of the Republic of Albania ${ }^{34}$ and the Law on Local Government, ${ }^{35}$ each function and authority transferred from the central government to the local one should be accompanied by a respective financial bill. However, local government representatives state that central government does not provide funding for the full accomplishment of the functions and competencies which have been transferred to local government. ${ }^{36}$

A series of Competitive Grants (as determined in 2007) have been allocated according to which local units may be entitled to funding after submitting their projects to MOES and after an evaluation by the relevant commission established for this purpose. Nevertheless, the capacity of local staff to elaborate quality projects and to absorb these funds is very limited.

The most important documents on pre-university education are the National Strategy on Education 2004-2015; 37 the National Strategy on Pre-education, ${ }^{38}$ which lays out the priorities for the period up to 2013 for the pre-education, basic (mandatory) education, secondary education and occupational education segments; and the Decentralisation Policy in the Sector of Pre-University Education. These strategies and pol-

34 Constitution of the Republic of Albania [last accessed 25 January 2011].

35 Ministry of Interior, op. cit.

36 Institute for Democracy and Mediation (2008) Moving towards Consolidated Interactions between the Local Government and Central Institutions at Local Level July, Tiranë.

37 Ministry of Education and Science National Education Strategy 2004-2015.

38 Ministry of Education and Science National Pre-University Education Development Strategy. 
icies aim to segregate responsibilities and functions in the education sector among the different levels of governance, as well as to identify conditions for the increase of accountability for those functions which are expected to be decentralised. However, much remains to be done in terms of the organisation of the drafting and monitoring of implementation, since this is the only way to improve both the quality of the decentralisation process and the provision of this service to the community. Besides these documents, there is a series of laws and sub-regulatory acts that aim to regulate relationships in pre-university education at central and local level.

Generally, access to pre-university education in Albania displays a low level of participation compared to OECD countries. This is explained by the low rates of attendance in secondary and higher education institutions. ${ }^{39}$ However, there is also a variation when regions within Albania are compared: an adult in Tiranë, for instance, attends education institutions for 3.5 years longer compared to the national average. ${ }^{40}$ In analysing the figures further, it is evident that the biggest discrepancy stands between urban and rural areas, with the latter suffering from less access to public services generally and to education in particular. School drop-out rates at the national level amount to $0.94 \%$, but most affected are children coming from families in need; the Roma community; children from remote areas; and girls residing in remote areas where a patriarchal mentality and social problems prevent them from accessing education. ${ }^{41}$

Nevertheless, if we are to consider the general national level, there has been a small increase in the enrolment rate for the school-age population compared with previous years: from $68 \%$ in $2007-2008$ to $68.1 \%$ the following year. However, expenditure on education as a percentage of the state budget and GDP has decreased: regarding total Budget expenditure, it has decreased from $11.1 \%$ in 2007 to $10.4 \%$ in $2009 .{ }^{42}$

Something that does need to be addressed is the actual system of vocational education and development, which continues to be very weak in Albania: it is not responsive to the demands of the labour market and continues to have fragile links with the social partners and interested stakeholders at large. Despite the reforms undertaken in the last years, this system has a very low reputation from a quality perspective and the percentage of those engaged in it is very low. ${ }^{43}$

During the past few years, Albania has undertaken serious reforms in the fields of higher education, research, science and technology, aiming at the quick economic development of the country and its integration into the European Union. The new Law on Higher Education ${ }^{44}$ has introduced greater flexibility and objectivity regarding the funding of universities, while the Higher Education Strategy sets out a number of ambitious goals to improve the performance of the university sector. Albania currently has eleven public higher education institutions and eighteen private licensed ones, and

39

41 ibid.

42 Albanian Institute of Statistics Albania in Figures 2010, [last accessed 27 January 2011].

43 Ministry of Education and Science National Pre-University Education Development Strategy.

44 Ministry of Education and Science Law on Higher Education, amended in 2010. 
the trend is towards rapid growth. ${ }^{45}$ Public universities are older and financed mostly by the state, in addition to the registration and other fees that they draw from students, whereas private universities are new, established after 2000 and self-financed through student fees determined by the institution itself or through donations.

The basic legal document on which higher education in Albania is based is Law No. 9741 from 2007 on Higher Education in Albania, amended recently in 2010. All higher education public institutions operate on the basis of this law, which allows for the founding and development of non-public higher education institutions. Under this law, a private higher education institution may only begin its operation after obtaining a licence. Licensing is carried out only on the fulfilment of the criteria set by the state and the standards adopted by the Council of Ministers, on the proposal of the Ministry of Education and Science. Also, according to this law, the Minister of Education and Science, based on the recommendations of the Accreditation Council, has the final decision on institutional accreditation and on higher public and private education programmes.

A national system of tariffs, implemented in recent years on the basis of ministerial competence, operates in all the universities of the country. The tariff system is based on the country's economic level. The amount is very low for further education and is common to all students regardless of the level of study, nationality, etc. Tariffs are higher in graduate education.

A recent report by the World Bank $^{46}$ warns that the poor quality of education is threatening economic growth in Albania. According to this report, over $51 \%$ of large firms in Albania, exporters in particular, reported in 2009a lack of knowledge among employees as their greatest obstacle. This situation is critical because these firms are a potential source of economic growth in the future. Nevertheless, despite these disadvantages in the skills of the labour force, Albania is not only not investing more than other countries but is instead spending significantly less on education than the rest of the region. The Albanian government dedicated $3.4 \%$ of gross domestic product to education in 2009 compared, firstly, to $3.5 \%$, which was the figure in the country for 2008; and, secondly, to $4.6 \%$, which is the average for the Balkans. ${ }^{47}$ Expenditure on scientific research takes place only at low levels - just $0.2 \%$ of gross domestic product, or at least ten times lower than the EU average.

A survey undertaken in 2010 nationally, with the specific aim of analysing the research capacities of universities in Albania, ${ }^{48}$ concludes that, apart from the overall identified need for more intensive research activity, additional problems also arise, such as: a lack of infrastructure to develop research (referring to public universities); shortages in the number of full-time academic staff as a result of the refusal of the Ministry of Education to approve the additional number of academic staff required (again re-

45 Swiss Agency for Development and Co-operation (2010) The Assessment of Research Capacities in Social Sciences in Albania March, Regional Research Promotion Programme in the Western Balkans (RRPP).

46 World Bank Trade and Development Report [last accessed 25 January 2011].

47 Albanian Institute of Statistics Albania in Figures 2010 [last accessed 27 January 2011].

48 Swiss Agency for Development and Co-operation, op. cit. 
ferring to public universities); a lack of funds for the development of scientific research activities; and the limited possibilities for the further skilling of academic staff, especially for advanced studies, $\mathrm{PhD}$ programmes and exchange experiences with similar universities abroad.

Governments have indeed undertaken some reforms, which have mainly consisted of opening the market to new universities, which has led to an increase in the number of students. However, the benefits of this increase are being threatened by the continuing decline in the quality of teaching.

An essential condition for addressing the above-described issues is the organisational restructuring of public universities. In addition, public funding systems need to provide incentives for these institutions to fulfil their respective missions of enhancing competitiveness and social cohesion. These will require moving increasingly towards performance-based funding systems. Public subsidies for university fees, for example, should be targeted toward students from poorer backgrounds and, over the longer term, linked to student loan systems. Such changes will require political determination from governments and a significant enhancement of the managerial capacity of public universities.

Albania faces multiple challenges in improving its research and development system, but the foundations for its longer-term effectiveness do need to be established now. The adaptation of existing knowledge should be emphasised, rather than innovation and the creation of new knowledge. In relation to research and development, links should be strengthened between public universities and private enterprises, as the biggest contribution that a research sector can make to a country is to help companies adopt and adapt new ideas and technologies from elsewhere. At the same time, private funding for research and development needs to increase, together with the employment of researchers in the private sector.

\section{Conclusions and recommendations}

Albania lacks clear strategies for the labour market. Nowadays, employment is the main problem that citizens report in their everyday conversations or in public surveys. This is noticeable because, so far, the economic model in transition has been ineffective in creating new jobs during the last decade. Participation in the labour market is extremely low for women and young people; this is significant when linked to the low level of education. There is a chance that the situation will deteriorate in the future, considering the aging of the population and, consequently, the exit from the labour market of a considerable part of the population.

The failure to create new jobs, besides being the main source of the inequalities that pervade Albanian society, is also a macroeconomic problem that must be faced by correcting the main causes which generate it: the low level of qualification of employees; the informal economy; and the interaction of the informal economy with high-cost labour.

The main problem stands within education in general and, in particular, with occupational/vocational schools. The present education system is failing to produce a critical mass of human capital that generates external positive factors for the entrepreneurship system. In comparison with other countries of the region, Albania suf- 
fers from significant setbacks, especially in the second tier of education, where registration in the school system is very low compared to other countries of the region. Therefore, the private sector remains locked in a low-quality human capital balance. This brings a low productivity to firms, a scant demand for skilled employment and few incentives for young people to invest in their education.

On the other hand, this vicious circle partially explains the emigration both of skilled workers and of the less skilled. This happens because the overall production of the system and, consequently, its aggregate demand for work are limited by these phenomena.

For its part, the extension of the informal economy makes employment policy interventions more fragile, exposing active and indispensable policies to the risk of tax evasion and corruption. This leads to the inefficient use of public resources, which are dedicated to the improvement of employment conditions for the most disadvantaged segments of the population.

In line with the above-mentioned practice, it is advisable to foster the growth of the employment capacity of the economy in conjunction with developing a skilled and professionally-educated structure for human capital. As long as economic policies are not oriented towards the structural adjustments which will improve the labour market, employment will be the constant illness of an economy that lacks the appropriate dynamic to improve the living conditions and incomes of Albanian society.

\section{References}

Agenda Institute (2008) Challenges facing Albanian youth on the road towards Employment.

Albanian National Institute of Statistics INSTAT (2006) Living Standard Measurement Survey 2005.

Albanian National Institute of Statistics INSTAT (2009) Labour Force Survey 2009 www.instat.gov.al.

Albanian National Institute of Statistics INSTAT (2010): Albania in Figures. www.instat.gov.al.

Commission of the European Communities (2009): Albania 2009 Progress Report, plus Commission Staff Working Document accompanying the communication from the Commission to the European Parliament and the Council Enlargement Strategy and Main Challenges 2009-2010.

Constitution of the Republic of Albania http://legislationline.org/documents/section/constitutions.

Council of Europe European Charter of Local Self-Government $\mathrm{http}: / /$ conventions.coe.int/treaty/en/treaties/html/122.htm.

Institute for Democracy and Mediation (2008) Moving towards Consolidated Interactions between the Local Government and Central Institutions at Local Level.

International Labour Organization ILO (2010) Analysis of the youth labour market in Albania. 
International Labour Organization ILO Decent Work Country Program 2008-2010.

Labour Code of the Republic of Albania (1995) http://www.sli.gov.al.

Law on Gender Equality in Albania No. 9198, dated 1 July 2004, http://www.sli.gov.al.

Ministry of Education and Science National Pre-University Education Development Strategy.

Ministry of Education and Science Law on Higher Education amended in 2010.

Ministry of Education and Science National Education Strategy 2004-2015.

Ministry of Finance Public Finance Sector Strategy.

Ministry of Interior National Strategy on Decentralisation and Local Governance.

Ministry of Labour, Social Affairs and Equal Opportunities Strategy for Social Inclusion 2007-2013.

Ministry of Labour, Social Affairs and Equal Opportunities System of Tariffs for Professional Education.

Ministry of Labour, Social Affairs and Equal Opportunities Sectoral Strategy on Employment and Vocational Training 2007-2013.

Ministry of Economy, Trade and Energy (2007) Regional Development Cross-Cutting Strategy.

Swiss Agency for Development and Co-operation Regional Research Promotion Programme in the Western Balkans.

University of Freiburg (2010) The Assessment of Research Capacities in Social Sciences in Albania.

World Bank (2006) Business Environment Snapshot for Albania.

World Bank (2007) Albania Country Brief 2007.

World Bank Trade and Development Report www.worldbank.org.

\section{Internet resource}

Albania to hold census in 2011

http://www.balkans.com/open-news.php?uniquenumber $=47384$ [last accessed 20 January 2011]. 